\title{
The transition from lead transparent to tin-opacified glaze productions in the western Islamic lands: al-Andalus, c. AD 875-929
}

\author{
Elena Salinas ${ }^{1}$, Trinitat Pradell ${ }^{1}$ \\ ${ }^{1}$ Physics Department and Barcelona Research Centre in Multiscale Science and Engineering, \\ Universitat Politècnica de Catalunya, Campus Diagonal Besòs, Av. Eduard Maristany, 10-14 \\ 08019 Barcelona, Spain
}

\begin{abstract}
The earliest glazed ware in al-Andalus is dated to the Emiral period (c. AD 850-875) and is not until the Caliphate of Córdoba (AD 929-1031) that a distinctive polychrome tin glaze started being produced. A short transition period (c. AD 875-925) in which elaborate monochrome and bichrome transparent glazes wares coexist with polychrome transparent and tin opaque glazed wares has been identified. The existence of a polychrome lead transparent glaze production in al-Andalus wares is demonstrated; it has distinctive composition and methods of production from monochrome and bichrome wares, and shares a distinctive absence of foot and overglaze application of the decorations with the tin-opacified wares. With regard to the possible routes of the introduction of the polychrome lead and tin glazes into the western Mediterranean the Tunisian connection seems completely discarded. Moreover, and although some similarities between the Cordoba and the Abbasid productions such as similar tin glaze recipe and decorative patterns and use of lead glazes, can be traced, the dissimilarities, such as, the use of overglaze decorations, absence of alkali transparent glazes, variances in the tableware shapes and absence of foot, are still more important, and do not support a clear link between them.
\end{abstract}




\section{INTRODUCTION}

It is generally accepted that glaze technology was not known during the early days of the introduction of Islam into the Iberian Peninsula (AD 711-c. 850) (CASAL et al. 2003, SALINAS 2013). The first glazed-ware workshop known so far is found in Bajjana/Pechina (southeast of al-Andalus) (CASTILLO et al. 1987; CASTILLO, MARTÍNEZ 1993) (c. AD 850-875) where monochrome and bichrome transparent lead glazes - green or honey colouredare documented. Those initial lead glazed productions expanded to other regions under the Independent Umayyad Emirate of al-Andalus (AD 756-929). These first glazed wares include a relatively rare luxurious production showing various decorative techniques (surfaces molded, incised or with applied threads) and new tableware forms (serving dishes, beakers, cups, pitchers). Later on, with the establishment of the Caliphate of Córdoba (AD 929-1031), a distinctive polychrome tin glaze production known as "verde y manganeso" started being produced. This polychrome tableware production coexisted with a large-scale and standardised monochrome transparent glaze production which does not include other decorative techniques and has a less careful execution and finishing than the Emiral one.

Archaeological evidence of a transition period dating between the Emiral and Caliphal productions (i.e., between the last quarter of the $9^{\text {th }}$ and the first quarter of the $10^{\text {th }}$ centuries) has been recently found in Madinat Qurtuba (Córdoba) (CÁNOVAS \& SALINAS, 2010; SALINAS 2013). In this transition period, monochrome and bichrome transparent glazed wares coexist with polychrome transparent glazed and also polychrome tin glazed wares. In particular, two well dated glazed ceramic assemblages from this transition period have been recently recovered in Córdoba, including both lead and tin glazed ceramics and showing different decorative techniques, shapes and colours. During this period Madinat Qurtuba (Cordoba) was the capital of the Emirate. These findings demonstrate that tin glazed wares started in alAndalus at the end of the independent Emirate, earlier than previously thought, and coexisting for a short period with the earlier monochrome and bichrome lead transparent glaze productions. Additionally, a new polychrome lead transparent production previously unknown has also been identified. These polychrome lead transparent wares have green and brown decorations like the later Caliphal polychrome tin glaze production.

Taking advantage of these two well dated glaze assemblages, the present study attempts, on the one hand, to recognise the earliest tin-opaque glaze productions in al-Andalus and how they connect to the later Caliphal tin glazed wares; and, on the other hand, to determine the relationship between the polychrome lead and both the earlier monochrome and bichrome productions and the later polychrome tin production. A second and more ambitious objective of this study is to identify the links with contemporary productions from other regions of the Islamic world, in particular with those from the Central Mediterranean and the Middle East, as well as the possible routes of the introduction of the lead and tin glazes into the western Mediterranean.

A comparative typological and decorative study of the sherds is performed. Moreover, in order to determine characteristics and methods of production of the different glazed wares, the ceramic pastes and glazes are analysed. Polished cross sections of ceramics and glazes and thin cross sections of the ceramics are analysed by optical microscopy, petrographic microscopy, and scanning Electron microscopy with energy-dispersive spectrometry (SEM-EDS). Micro$\mathrm{X}$-ray diffraction analysis was also carried out to determine the nature of some of the crystallites present in the glazes. 


\subsection{Archaeological and historic context}

Two glazed ware assemblages were discovered in archaeological excavations carried out in the eastern area of the Islamic medieval Córdoba, in two different suburbs outside the medina walls, but not far from the city centre.

The first assemblage was excavated on the right bank of the river Guadalquivir, in a land plot called Posada de la Herradura (MORENO et al. 2006). During the Islamic period this area belonged to the "Sabular" suburb, located very close to the "madina" on the "Bab al-Hadid", that departed from the eastern gate (IBN HAYYĀN 2001). During the archaeological excavations some Andalusi houses were identified. The wares were recovered from a cesspit of one of the houses, originally a latrine, where waste and broken pottery were thrown. Once closed, the pit was sealed, without any subsequent alteration. Glazed wares, but also unglazed pieces, such as cooking pots, lids and painted pitchers were recovered. The glazed pieces show different decorative techniques and colours: a single colour glaze -monochrome-, two colour glazes one at each side of the ware -bichrome-, or a combination of several colours polychrome-. A "felus" (copper coin) corresponding to an issue of the Independent Emirate, minted during the 'Abd al-Rahman II period (AD 822-852) (FROCHOSO 2001), was also found, providing a terminus post quem for the cesspit dating. However, it is the unglazed ceramics group that facilitate a more accurate Late Emiral date (SALINAS 2013); showing identical forms and decorations to those at contemporary sites from Córdoba, such as Cercadilla (FUERTES, GONZÁLEZ 1994) and the craft area of Zumbacón (LARREA 2008) and evolved forms from those of the Early Emirate period illustrated in the "Shaqunda" ceramic assemblage (CASAL et al. 2005).

The second glazed ware assemblage was excavated also in the eastern area of the city, "al-yiha al-Sarqiyya", the current Axerquía of Córdoba, in two adjacent land plots at Maria Auxiliadora street (CÁNOVAS 2006). Some historians have identified this area as the "Munyat al-Mugira" suburb where the mosque of "Masjid al-Mugira", current parish of San Lorenzo, was located. The early medieval historical sequence of the archaeological excavation is defined by the presence of three low-lying layers: a stream filled with rubbish and broken ceramic, followed by a great gully used as a dump, and a landfill, all sealed by a platform in the Caliphate period. A collection of glazed and unglazed wares showing numerous parallels with other $9^{\text {th }}$ century Córdoba archaeological sites (e.g. Cercadilla) was recovered. Regarding the glazed pottery, most of the sherds are monochrome or bichrome, and one is polychrome.

Consequently, both sets of ceramics were contemporary and dated to the late Emirate (last quarter of the $9^{\text {th }}$ - first quarter of the $10^{\text {th }}$ centuries). This period is characterised by the first fitna or civil war and the ulterior pacification of the Islamic territories by 'Abd al-Rahman III al-Nasir prior to his self-proclamation as Caliph. 
(A)

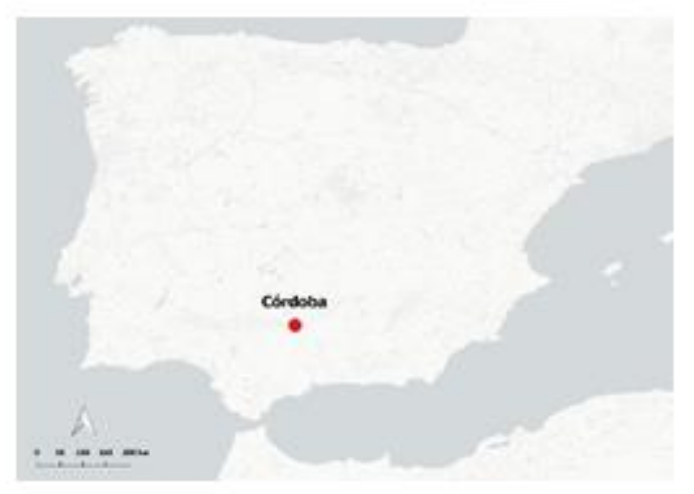

(B)

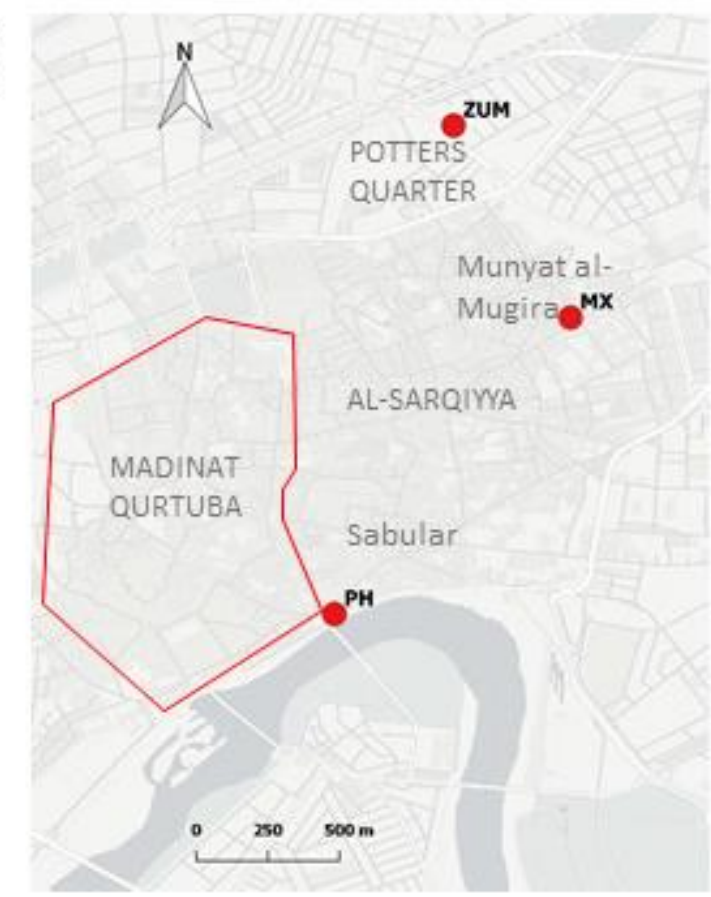

Figure 1. Plan of Cordoba where Posada de la Herradura (PH) and María Auxiliadora (MX) archaeological sites are marked.

\section{MATERIALS AND METHODS}

\subsection{Glazed ceramic samples}

A total of twenty two glazed sherds were selected from the two archaeological sites (PH for those found in Posada de la Herradura and MX in Maria Auxiliadora). The selection includes examples of different technological traditions: transparent lead glazes and tin-glazed wares. The most interesting aspect of the selected sherds is the heterogeneity. They show different shapes, colours and decorative techniques and patterns, which may indicate that they come from different workshops. Following the classification of Rosselló (1978), most of them belong to the table ware group (bowls, beakers, serving dishes, pitchers) but also a jar ("orza") and an oil lamp ("candil") are found. Heterogeneity is also observed in the various types of serving dishes and pitchers. The ceramics show also a broad range of colours including honey, green, brown, cream and white. However, the most remarkable aspect is the diversity of decorations; they appear incised with applications of threads or paintings and some are moulded. It is worth highlighting that such decorative richness is accompanied by a high technical execution which 
did not survive later in the Caliphal period. Consequently, this appears to be a highly valued ware destined to a smaller selective market.

(A)

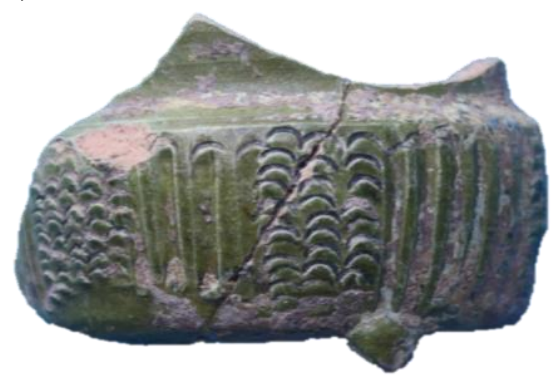

(C)

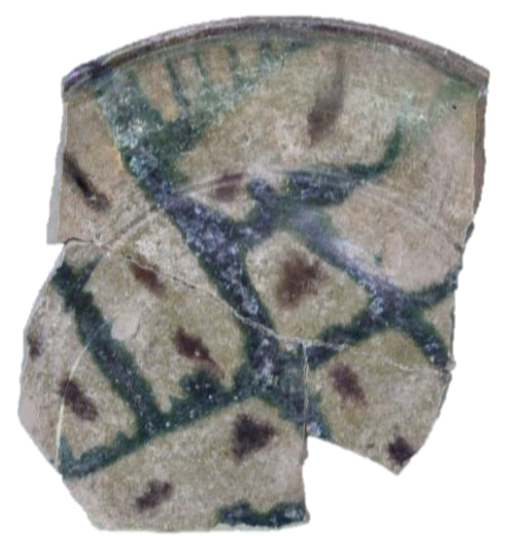

(B)

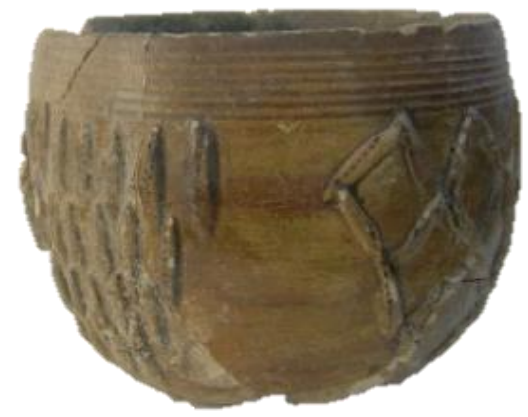

(D)

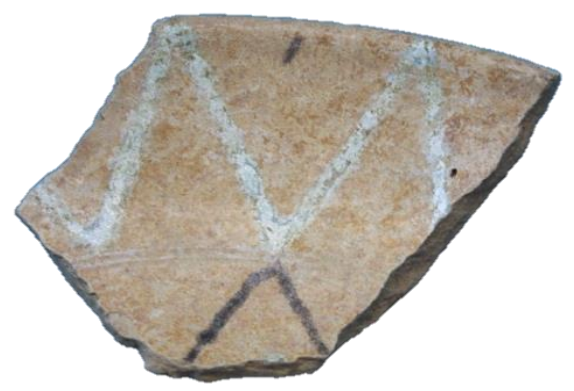

Figure 2. Representative glazed ceramics from Posada de la Herradura $(\mathrm{PH})$ and María Auxiliadora (MX): (A) green monochrome (MX25), (B) bichrome, honey outside-green inside (PH10.3), (C) polychrome transparent (PH12), (D) polychrome opaque (PH14).

The glazed wares are sorted in two main categories according to the glazing technique: transparent, including monochrome, bichrome and polychrome; and opaque, polychrome glazes.

The monochrome transparent glaze group is composed of seven samples and includes five pitchers (MX20, MX21, MX22, MX23, MX25), one foot-free dish (PH20) and one oil-lamp (PH8). Four of them have incised decorations (PH8, MX20, MX21 and MX25) (see Figure 2).

The bichrome transparent group is composed of five samples including three beakers (MX26, PH10.1 and PH10.3), one pitcher (PH9) and one foot-free serving dish with winged rim(PH11.1). Regarding the decoration, three have threads applied on the surface of the glaze (MX26, PH9 and PH10.3) (see Figure 2) and one is moulded (PH10.1). Four of them have a honey outer surface while the inner surface is green and one (MX26) is green outside and honey inside.

The polychrome transparent group includes five sample:, three foot-free serving dishes with diverging or straight profiles and colour decorations applied on the inner surface (P11.3, PH12, PH16) (see Figure 2) and one cup (PH15.2) and one jar (PH18) with colour decorations applied on the outer side.

Finally, from the polychrome tin-opaque glazes, four are hemispherical foot-free serving dishes (H13.5, PH14, PH50) (see Figure 2) and one is a closed form (PH19). 
Table 1. Classification of the glazed wares. g- green glaze, h- honey glaze, w- white glaze, d- decorated, $\mathrm{i}$ - inner glaze, $\mathrm{o}$ - outer glaze.

\begin{tabular}{|c|c|c|c|c|}
\hline Type & & Samples & glaze & Shards \\
\hline \multirow{6}{*}{$\begin{array}{l}\text { Transparent } \\
\text { glazes }\end{array}$} & \multirow{2}{*}{$\begin{array}{l}\text { Monochrome } \\
\text { Transparent } \\
\text { (MT) }\end{array}$} & \multirow{2}{*}{7} & $\mathrm{~g}$ & PH8, MX20, MX23, MX25 \\
\hline & & & $\mathrm{h}$ & PH20, MX21, MX22 \\
\hline & \multirow{2}{*}{$\begin{array}{c}\text { Bichrome } \\
\text { Transparent } \\
\text { (BT) }\end{array}$} & \multirow[t]{2}{*}{5} & $\mathrm{~h}(\mathrm{o}) / \mathrm{g}(\mathrm{i})$ & PH9, PH10.1, PH10.3, PH11.1 \\
\hline & & & $\mathrm{g}(\mathrm{o}) / \mathrm{h}(\mathrm{i})$ & MX26 \\
\hline & \multirow{2}{*}{$\begin{array}{c}\text { Polychrome } \\
\text { Transparent } \\
\text { (PT) }\end{array}$} & \multirow{2}{*}{5} & $\mathrm{t}(\mathrm{o}) / \mathrm{d}(\mathrm{i})$ & PH11.3, PH12, PH16 \\
\hline & & & $\mathrm{t}(\mathrm{i}) / \mathrm{d}(\mathrm{o})$ & PH18, PH15.2 \\
\hline \multirow{2}{*}{$\begin{array}{l}\text { Opaque } \\
\text { glazes }\end{array}$} & \multirow{2}{*}{$\begin{array}{l}\text { Tin opaque } \\
\text { (TO) }\end{array}$} & \multirow{2}{*}{4} & $\mathrm{w}(\mathrm{o}) / \mathrm{d}(\mathrm{i})$ & PH13.5, PH14, PH50 \\
\hline & & & w (i)/d (o) & PH19 \\
\hline
\end{tabular}

\subsection{Analytical techniques}

Polished sections through the glazes and into the bodies of the sherds were prepared and coated with a sputtered carbon layer $(<20 \mu \mathrm{m}$ thick). The polished sections were examined at the Universitat Politècnica de Catalunya (Barcelona) both in reflected light with an optical microscope $(\mathrm{OM})$, and in a crossbeam workstation (Zeiss Neon 40) equipped with scanning electron microscopy (SEM) GEMINI (Shottky FE) column with attached EDS (INCAPentaFETx 3 detector, $30 \mathrm{~mm}^{2}$, ATW2 window, resolution $123 \mathrm{eV}$ at the $\mathrm{Mn} \mathrm{K \alpha}$ energy line), operated at $20 \mathrm{kV}$ acceleration voltage with $1.1 \mathrm{~nm}$ lateral resolution, 20nA current, $7 \mathrm{~mm}$ working distance and 120s measuring time. The glaze and body microstructures were studied and recorded in Back-scattered Electron mode (BSE) in which the different phases present could be distinguished on the basis of their atomic number contrast. BSE images of the microstructures were obtained at $20 \mathrm{kV}$ acceleration voltage.

The chemical compositions of the bodies were determined by analysing a minimum of two areas, about $3 \mathrm{~mm} \times 2 \mathrm{~mm}$. Because of the porosity of the bodies, the analyses were normalised to $100 \mathrm{wt} \%$, and then averaged. Typical paste totals were about $60 \%$ while glaze totals varied between $97 \%$ and $101 \%$ mainly due to the variable state of preservation of the glazes. For the glazes, the areas analysed were somewhat smaller, and as far as possible, were chosen to avoid areas of weathered glaze and areas near to the glaze-body interface; the results were again averaged. A selection of the non-plastic inclusions within the bodies, and opacifiers and other particles in the glazes were also analysed. An EDS elemental microanalysis system calibrated with oxide and mineral standards was used to determine the microstructure and composition of the glazes, and high lead - K229- and alkali -SRM612- glass standards were also used to validate the data (Geller Microanalytical Laboratory, MA, USA). Typical detection limits are $0.1 \%$ for $\mathrm{Na}, \mathrm{Mg}, \mathrm{Al}, \mathrm{P}, \mathrm{K}, \mathrm{Ca}, \mathrm{Ti}, \mathrm{Mn}$ and $\mathrm{Fe}, 0.2 \%$ for $\mathrm{Si}$ and $\mathrm{Cu}, 0.3 \%$ for $\mathrm{Sn}$ and $\mathrm{Sb}$ and 0.4 for $\mathrm{Pb}$.

$\mu$-XRD data were obtained at the Materials Science and Powder Diffraction beamline (MCPDS BL04) in the Synchrotron Light Facility Alba-Cells (Cerdanyola, Spain) of polished thin cross 
sections (about $200 \mu \mathrm{m}$ thick) of the stained glasses in transmission geometry, sing $0.4243 \AA$ wavelength (30 keV), a $20 \times 20 \mu \mathrm{m}^{2}$ spot size, and a CCD camera, SX165 (Rayonix, L.L.C., Evanston, IL) detector.

\section{RESULTS}

The chemical compositions of the bodies, obtained by SEM-EDS, are included in Table 2. The chemical compositions of the transparent glazes are given in Table 3 and of the opaque glazes in Table 4.

\subsection{Body composition}

The ceramic bodies are made of calcareous clays (i.e., limestone-rich clays with $\mathrm{CaO}$ content varying between 11.9 and $22.0 \% \mathrm{CaO}$ ) with a range of reddish to buff and grey colours, depending on whether the firing atmosphere was reducing (Figure 3A) or oxidizing (Figure 3B). Besides, the buff color predominates in the tin glazed wares. In general, they are high fired. Both the microstructure of the pastes and also the mineralogical composition dominated by the presence of quartz, anorthite (calcium rich feldspar, $\mathrm{Ca}, \mathrm{Na}) \mathrm{Al}_{2} \mathrm{Si}_{2} \mathrm{O}_{8}$ ) and fassaitic pyroxens $\mathrm{Ca}\left(\mathrm{Mg}, \mathrm{Fe}^{3+}, \mathrm{Al}\right)(\mathrm{Si}, \mathrm{Al})_{2} \mathrm{O}_{6}$ - as determined by XRD. Anorthite forms in fine calcareous pastes fired at temperature above $950^{\circ} \mathrm{C}$; fassaitic pyroxens form when magnesium is also present and the atmosphere is partly reducing at temperatures above $900^{\circ} \mathrm{C}$. Temperatures above $1050^{\circ} \mathrm{C}$ are not likely as mullite is not found. Some magnesian calcite $-(\mathrm{Ca}, \mathrm{Mg}) \mathrm{CO}_{3}-$ gehlenite $\mathrm{CaAl}\left(\mathrm{AlSiO}_{7}\right)$ - and biotite $-\mathrm{K}(\mathrm{Mg}, \mathrm{Fe}) \mathrm{AlSi}_{3} \mathrm{O}_{10^{-}}$are also found but they are related to the medium sized filling inclusions: mainly quartz grains, but also biotite micas, microfossils and $\mathrm{red} / \mathrm{black}$ ferruginous nodules. All the particles are visible under the optical microscope. Very large elongated porosity oriented parallel to the surface is also found in most of the sherds.

A distinctive feature in most of the MX (MX20, MX21, MX22 and MX23) bodies is the inclusion of large white calcium-rich and black/red iron-rich clay nodules, (Figure 3C and Figure 3D). We have noted the presence of these white clay nodules in contemporary sherds found at the Zumbacón craft area (Córdoba) (LARREA 2008) whose peak activity was during the Emirate period, and continued subsequently in "green and brown" tin-glazed wares found at Madinnat al-Zahrā' and Córdoba, dated from the Caliphal to the Almohad periods $\left(10^{\text {th }}-13^{\text {th }}\right.$ centuries). In fact, in the Zumbacón craft area more than 100 kilns, of which a large number were producing unglazed and glazed pottery in the Emiral period, have been found. 
(A)

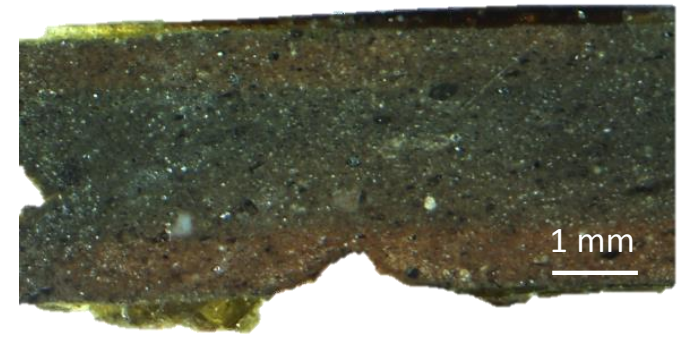

(C)

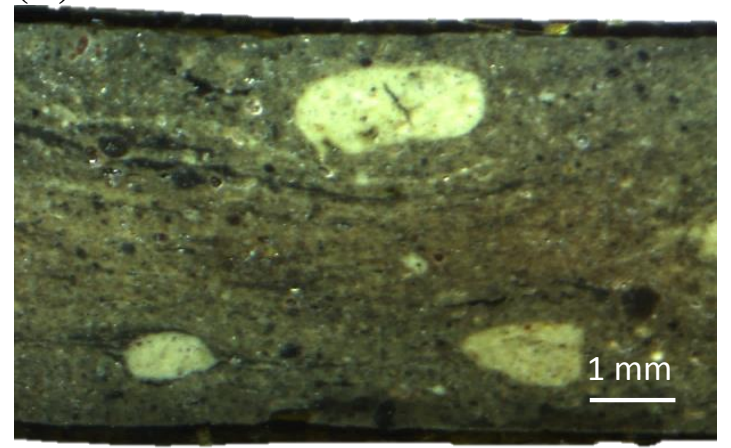

(B)

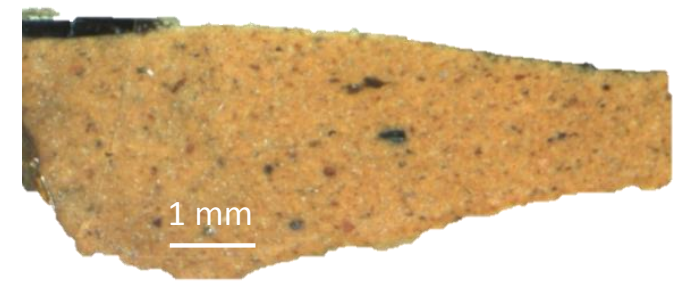

(D)

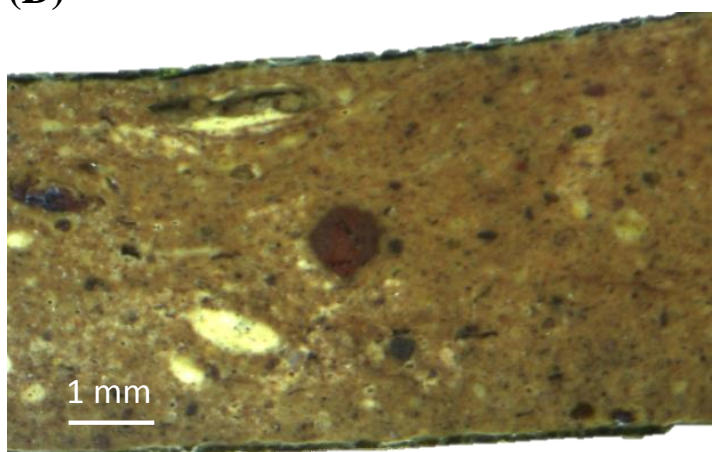

Figure 3. Ceramic fabrics. Fine limestone; (A) reduced paste (PH12) and (B) oxidized paste (PH15.2). Typical paste from the Zumbacón workshop (Cordoba) showing the characteristic large white calcium rich and red/black iron rich nodules; (C) reduced paste (MX21) and (D) oxidized paste (MX23). 
Table 2. Chemical compositions of the Córdoba ceramic bodies determined by SEM-EDS (wt\% normalised to $100 \mathrm{wt} \%$ ). The data are the average over at least two analyses taken in different areas of the ceramic bodies. ${ }^{*}$ white calcium rich clay nodule.

\begin{tabular}{|c|c|c|c|c|c|c|c|c|c|c|c|}
\hline & & $\mathrm{Na}_{2} \mathrm{O}$ & $\mathrm{MgO}$ & $\mathrm{Al}_{2} \mathrm{O}_{3}$ & $\mathrm{SiO}_{2}$ & $\mathrm{~K}_{2} \mathrm{O}$ & $\mathrm{P}_{2} \mathrm{O}_{3}$ & $\mathrm{CaO}$ & $\mathrm{TiO}_{2}$ & $\mathrm{FeO}$ & $\mathrm{PbO}$ \\
\hline \multirow{8}{*}{$\begin{array}{c}\text { monochrome } \\
\text { transparent glazes }\end{array}$} & PH8 & 0.6 & 2.0 & 12.9 & 53.6 & 1.7 & 2.7 & 20.0 & 0.6 & 4.8 & 1.1 \\
\hline & MX20 & 0.5 & 2.0 & 14.2 & 58.7 & 0.4 & 2.7 & 14.9 & 0.8 & 5.0 & 0.9 \\
\hline & MX20* & 0.4 & 2.6 & 14.3 & 50.7 & 2.3 & 1.5 & 20.9 & 0.8 & 5.6 & 1.1 \\
\hline & MX21 & 0.6 & 2.1 & 14.6 & 58.5 & 0.0 & 3.1 & 14.1 & 0.8 & 5.5 & 0.8 \\
\hline & MX23 & 0.8 & 2.0 & 15.5 & 58.4 & 1.1 & 3.3 & 12.1 & 0.9 & 5.7 & 0.2 \\
\hline & MX25 & 0.5 & 2.1 & 15.2 & 56.9 & 1.6 & 3.5 & 12.6 & 0.9 & 6.0 & 0.7 \\
\hline & MX22 & 0.5 & 2.0 & 14.3 & 55.4 & 0.9 & 3.0 & 17.1 & 0.8 & 5.2 & 0.9 \\
\hline & $\mathrm{PH} 20$ & 0.8 & 2.6 & 14.2 & 52.6 & 0.7 & 1.9 & 20.0 & 0.7 & 5.4 & 0.9 \\
\hline \multirow{5}{*}{$\begin{array}{l}\text { bichrome transparent } \\
\text { glazes }\end{array}$} & MX26 & 0.5 & 2.6 & 16.3 & 53.5 & 1.3 & 3.8 & 14.7 & 0.7 & 6.6 & 0.0 \\
\hline & PH9 & 0.7 & 2.4 & 14.7 & 52.1 & 0.8 & 2.9 & 20.2 & 0.6 & 4.9 & 0.6 \\
\hline & PH10.3 & 0.4 & 2.5 & 14.3 & 52.1 & 0.6 & 3.1 & 20.4 & 0.7 & 5.8 & 0.5 \\
\hline & PH10.1 & 0.8 & 2.0 & 13.6 & 56.6 & 2.0 & 2.3 & 15.9 & 0.7 & 5.0 & 1.1 \\
\hline & PH11.1 & 0.5 & 2.1 & 14.3 & 53.3 & 0.5 & 3.0 & 19.6 & 0.6 & 5.4 & 0.4 \\
\hline \multirow{5}{*}{$\begin{array}{l}\text { polychrome } \\
\text { transparent glazes }\end{array}$} & PH11.3 & 0.4 & 2.2 & 13.4 & 54.2 & 1.6 & 3.7 & 18.4 & 0.7 & 4.9 & 1.2 \\
\hline & PH12 & 0.5 & 2.1 & 14.0 & 58.6 & 1.4 & 3.2 & 14.3 & 0.8 & 4.9 & 0.5 \\
\hline & PH15.2 & 0.8 & 1.9 & 13.5 & 50.3 & 1.8 & 3.0 & 21.9 & 0.7 & 4.5 & 1.2 \\
\hline & PH16 & 0.7 & 2.3 & 14.2 & 52.0 & 1.3 & 2.8 & 20.8 & 0.5 & 5.0 & 0.4 \\
\hline & PH18 & 0.6 & 2.4 & 14.3 & 52.9 & 0.6 & 2.7 & 20.5 & 0.6 & 5.0 & 0.5 \\
\hline \multirow{5}{*}{$\begin{array}{l}\text { polychrome tin } \\
\text { opaque glazes }\end{array}$} & PH19 & 0.5 & 2.3 & 13.8 & 52.3 & 0.5 & 3.1 & 21.6 & 0.7 & 5.0 & 0.1 \\
\hline & PH13.5 & 0.7 & 2.4 & 13.1 & 52.2 & 0.7 & 2.5 & 22.0 & 0.8 & 5.0 & 0.5 \\
\hline & PH14B & 0.7 & 2.2 & 13.9 & 54.5 & 1.6 & 2.6 & 18.8 & 0.7 & 5.1 & 0.3 \\
\hline & PH14A & 0.8 & 2.2 & 14.3 & 54.2 & 0.8 & 3.1 & 18.5 & 0.9 & 5.0 & 0.3 \\
\hline & PH50 & 1.2 & 2.4 & 13.8 & 51.5 & 1.0 & 1.9 & 20.6 & 0.7 & 5.5 & 0.5 \\
\hline
\end{tabular}

\subsection{Transparent lead glazes}

The chemical analyses of the monochrome, bichrome and polychrome transparent glazes are shown in Table 3. They include lead $(<55 \% \mathrm{PbO})$ and high lead $(>55 \% \mathrm{PbO})$ glazes. All the monochrome glazes are lead (43-55\% PbO), while all the polychrome glazes are high lead (56$67 \% \mathrm{PbO}$ ). Bichrome glazes show a larger variability, 48-61\% $\mathrm{PbO}$ and include both kinds: lead and high lead. Calcium and aluminium contents are more variable, between $1-5.5 \% \mathrm{CaO}$ and $0.4-5 \% \mathrm{Al}_{2} \mathrm{O}_{3}$, and higher for the monochrome and bichrome than for the polychrome glazes. Sodium and magnesium contents are very low in all cases, even below the detection limit in some cases. 
Table 3. Chemical compositions of Córdoba bulk monochrome transparent glazes determined by SEMEDS (wt \% normalised to $100 \mathrm{wt} \%$ ). The data are the average over at least two analyses taken in different areas of the glazes. Typical standard deviations are: 0.3 for $\mathrm{Na}_{2} \mathrm{O}, \mathrm{MgO}, \mathrm{K}_{2} \mathrm{O}, \mathrm{FeO}$ and $\mathrm{PbO}, 0.4$ for $\mathrm{CuO}$ and $\mathrm{Sn}_{2} \mathrm{O}, 0.9$ for $\mathrm{Al}_{2} \mathrm{O}_{3}$ and $\mathrm{SiO}_{2}$, and 1.5 for $\mathrm{CaO}$.

${ }^{1} \mathrm{~g}$ - green glaze, h- honey glaze, $\mathrm{h}^{*}$ - honey mottled. ${ }^{2} \mathrm{i}$ - inner glaze, $\mathrm{o}-$ outer glaze

\begin{tabular}{|c|c|c|c|c|c|c|c|c|c|c|c|c|c|c|}
\hline & Sample & Glaze $^{1}$ & Side $^{2}$ & $\mathrm{Na}_{2} \mathrm{O}$ & $\mathrm{MgO}$ & $\mathrm{Al}_{2} \mathrm{O}_{3}$ & $\mathrm{SiO}_{2}$ & $\mathrm{~K}_{2} \mathrm{O}$ & $\mathrm{CaO}$ & $\mathrm{TiO}_{2}$ & $\mathrm{MnO}_{2}$ & $\mathrm{FeO}$ & $\mathrm{CuO}$ & $\mathrm{PbO}$ \\
\hline \multirow{14}{*}{$\begin{array}{c}\text { monochrome } \\
\text { transparent } \\
\text { glazes }\end{array}$} & \multirow{2}{*}{ PH8 } & $\mathrm{g}$ & i & 0.2 & 0.5 & 2.7 & 32.6 & 1.1 & 3.8 & 0.2 & & 1.1 & 3.9 & 53.8 \\
\hline & & $\mathrm{g}$ & o & 0.2 & 0.6 & 2.7 & 32.4 & 1.2 & 3.9 & 0.1 & & 1.2 & 3.0 & 54.8 \\
\hline & \multirow{2}{*}{ MX20 } & $\mathrm{g}$ & $\mathrm{i}$ & 0.7 & 0.6 & 3.9 & 36.7 & 1.4 & 4.2 & 0.2 & & 1.7 & 2.0 & 48.7 \\
\hline & & $\mathrm{g}$ & o & 0.5 & 0.6 & 3.6 & 36.3 & 1.4 & 4.4 & b.d. & & 2.6 & 1.3 & 49.1 \\
\hline & \multirow{2}{*}{ MX21 } & $\mathrm{h}$ & $\mathrm{i}$ & 0.5 & 0.4 & 5.0 & 36.7 & 1.7 & 4.4 & 0.3 & & 2.0 & - & 49.1 \\
\hline & & $\mathrm{h}$ & o & 0.6 & 0.5 & 5.2 & 38.7 & 1.9 & 5.1 & 0.5 & & 2.3 & - & 45.2 \\
\hline & \multirow{2}{*}{ MX23 } & $\mathrm{g}$ & $\mathrm{i}$ & 0.6 & 0.7 & 4.4 & 39.5 & 2.1 & 5.6 & 0.5 & & 1.8 & 1.2 & 43.5 \\
\hline & & $\mathrm{g}$ & o & 0.7 & 0.7 & 4.2 & 38.4 & 1.9 & 4.8 & 0.3 & & 2.0 & 1.9 & 45.2 \\
\hline & \multirow{2}{*}{ MX25 } & $\mathrm{g}$ & $\mathrm{i}$ & 0.4 & 0.4 & 4.1 & 35.7 & 1.4 & 1.5 & 0.2 & & 1.1 & 1.7 & 53.5 \\
\hline & & $\mathrm{g}$ & o & 0.4 & 0.4 & 4.3 & 36.1 & 1.5 & 2.2 & 0.2 & & 1.2 & 1.7 & 51.8 \\
\hline & \multirow{2}{*}{ MX22 } & $\mathrm{h}^{*}$ & $\overline{\mathrm{i}}$ & 0.4 & 0.5 & 4.1 & 34.6 & 1.8 & 4.9 & 0.3 & & 3.6 & - & 49.8 \\
\hline & & $\mathrm{h}^{*}$ & o & 0.4 & 0.6 & 4.1 & 33.0 & 1.6 & 4.4 & 0.1 & & 3.3 & - & 52.4 \\
\hline & \multirow{2}{*}{ PH20 } & $\mathrm{h}$ & $\mathrm{i}$ & 0.5 & 0.8 & 3.6 & 33.3 & 2.0 & 5.6 & 0.1 & & 5.5 & 0.6 & 47.2 \\
\hline & & $\mathrm{h}$ & o & 0.3 & 0.8 & 3.4 & 36.6 & 2.3 & 5.2 & 0.4 & & 3.7 & 1.0 & 47.2 \\
\hline \multirow{10}{*}{$\begin{array}{l}\text { bichrome } \\
\text { transparent } \\
\text { glazes }\end{array}$} & \multirow{2}{*}{ MX26 } & $\mathrm{g}$ & o & 0.4 & 0.5 & 4.1 & 36.0 & 1.2 & 2.6 & 0.1 & 0.4 & 1.5 & 1.7 & 51.4 \\
\hline & & $\mathrm{h}$ & $\mathrm{i}$ & 0.3 & 0.6 & 4.1 & 35.6 & 1.4 & 3.1 & 0.2 & - & 3.0 & - & 51.7 \\
\hline & \multirow{2}{*}{ PH9 } & $\mathrm{h}$ & o & 0.3 & 0.6 & 3.1 & 36.9 & 1.5 & 4.0 & 0.3 & - & 2.4 & 0.6 & 50.5 \\
\hline & & $\mathrm{g}$ & $\mathrm{i}$ & 0.3 & 0.6 & 3.5 & 35.2 & 2.5 & 3.7 & 0.1 & - & 1.3 & 2.5 & 50.3 \\
\hline & \multirow{2}{*}{ PH10.3 } & $\mathrm{h}$ & o & 0.0 & 0.1 & 1.1 & 30.5 & 0.3 & 1.7 & 0.1 & - & 5.6 & - & 60.7 \\
\hline & & $\mathrm{g}$ & $\mathrm{i}$ & 0.2 & 0.3 & 2.0 & 32.0 & 0.8 & 2.7 & 0.2 & - & 0.8 & 2.5 & 58.6 \\
\hline & \multirow{2}{*}{ PH10.1 } & $\mathrm{h}$ & o & 0.5 & 0.6 & 3.0 & 37.3 & 1.6 & 4.0 & 0.2 & - & 5.2 & - & 47.5 \\
\hline & & $\mathrm{g}$ & $\mathrm{i}$ & 0.6 & 0.5 & 3.3 & 37.5 & 1.7 & 3.9 & 0.1 & - & 1.2 & 2.3 & 49.0 \\
\hline & \multirow{2}{*}{ PH11.1 } & $\mathrm{h}$ & o & 0.2 & 0.3 & 1.7 & 32.9 & 0.7 & 2.8 & 0.2 & - & 5.7 & - & 55.6 \\
\hline & & $\mathrm{g}$ & $\mathrm{i}$ & 0.3 & 0.5 & 1.9 & 34.6 & 0.6 & 3.0 & b.d. & - & 1.0 & 2.4 & 55.9 \\
\hline \multirow{16}{*}{$\begin{array}{c}\text { polychrome } \\
\text { transparent } \\
\text { glazes }\end{array}$} & \multirow{3}{*}{ PH11.3 } & $\mathrm{b}$ & $\mathrm{d}$ & 0.1 & 0.3 & 0.4 & 30.4 & 0.1 & 1.3 & & 2.2 & 0.5 & & 64.8 \\
\hline & & $\mathrm{t}$ & $\mathrm{d}$ & & 0.3 & 0.5 & 32.1 & 0.1 & 1.6 & 0.2 & & 0.4 & & 64.6 \\
\hline & & $\mathrm{t}$ & $\mathrm{u}$ & 0.2 & 0.4 & 0.6 & 29.9 & 0.2 & 1.5 & & & 0.5 & & 67.4 \\
\hline & \multirow{4}{*}{ PH12 } & $\mathrm{b}$ & $\mathrm{d}$ & 0.3 & 0.2 & 1.3 & 36.8 & 0.2 & 2.3 & & 2.1 & 0.6 & & 56.2 \\
\hline & & $\mathrm{g}$ & $\mathrm{d}$ & 0.4 & 0.4 & 1.4 & 35.8 & 0.4 & 2.3 & & & 0.7 & 3.2 & 55.5 \\
\hline & & $\mathrm{t}$ & d & 0.2 & 0.5 & 2.4 & 34.9 & 0.5 & 2.6 & & & 0.9 & & 58.0 \\
\hline & & $\mathrm{t}$ & $\mathrm{u}$ & 0.2 & 0.4 & 1.7 & 32.7 & 0.3 & 2.4 & & & 0.7 & & 61.2 \\
\hline & \multirow{3}{*}{ PH15.2 } & $\mathrm{b}$ & $\mathrm{d}$ & 0.2 & 0.2 & 0.4 & 34.3 & 0.8 & 1.4 & & 3.9 & 0.4 & 0.2 & 58.1 \\
\hline & & $\mathrm{g}$ & d & 0.5 & 0.5 & 1.5 & 33.2 & 1.4 & 2.5 & & & 0.9 & 1.1 & 58.0 \\
\hline & & $\mathrm{t}$ & $\mathrm{u}$ & 0.2 & 0.3 & 1.6 & 30.7 & 1.5 & 2.5 & 0.1 & & 0.5 & & 62.5 \\
\hline & \multirow{2}{*}{ PH16 } & $g^{*}$ & $\mathrm{~d}$ & 0.2 & 0.3 & 1.5 & 32.8 & 0.5 & 3.0 & 0.1 & & 0.7 & 0.1 & 61.0 \\
\hline & & $\mathrm{t}$ & $\mathrm{u}$ & 0.1 & 0.5 & 1.9 & 34.6 & 0.7 & 3.2 & 0.1 & & 0.8 & & 58.3 \\
\hline & \multirow{4}{*}{ PH18 } & $\mathrm{b}$ & $d$ & 0.0 & 0.1 & 0.4 & 31.3 & 0.5 & 0.7 & & 0.6 & 0.6 & & 65.7 \\
\hline & & $\mathrm{g}$ & d & 0.1 & 0.2 & 0.4 & 39.3 & 0.4 & 1.2 & & & 0.1 & 3.5 & 54.9 \\
\hline & & $\mathrm{t}$ & d & 0.1 & 0.2 & 1.0 & 32.6 & 1.2 & 2.2 & & & 0.4 & & 62.3 \\
\hline & & $\mathrm{t}$ & $\mathrm{u}$ & 0.1 & 0.3 & 1.0 & 33.2 & 1.2 & 1.8 & & & 0.5 & & 61.8 \\
\hline
\end{tabular}


All the glazes show a minimal glaze-ceramic interface, small bubbles and two kinds of fissures: those perpendicular to the surface are often a consequence of the differences in the shrinkage of glaze and paste during the cooling; and those parallel to the surface are normally related to a low firing temperature but when present near the surface are normally due to weathering (Figure 4A). In those sherds found in the Posada de la Herradura, the glazes are more weathered, with lead leaching and posterior recrystallisation of lead and calcium phosphates and carbonates inside bubbles, in the cracks and on the surface where they act as cement for soil particles (Figure 4B). Nevertheless, most of the glazes appear relatively well preserved, in particular those from Maria Auxiliadora.
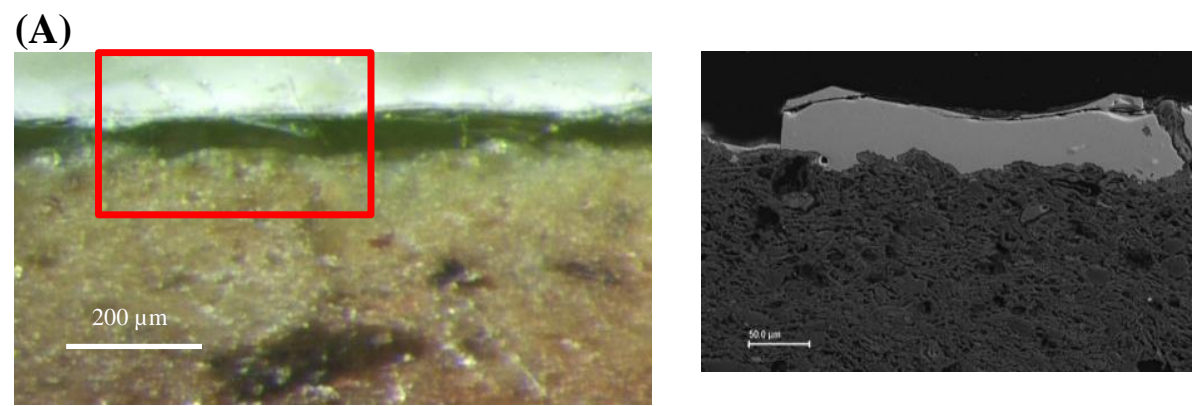

(B)
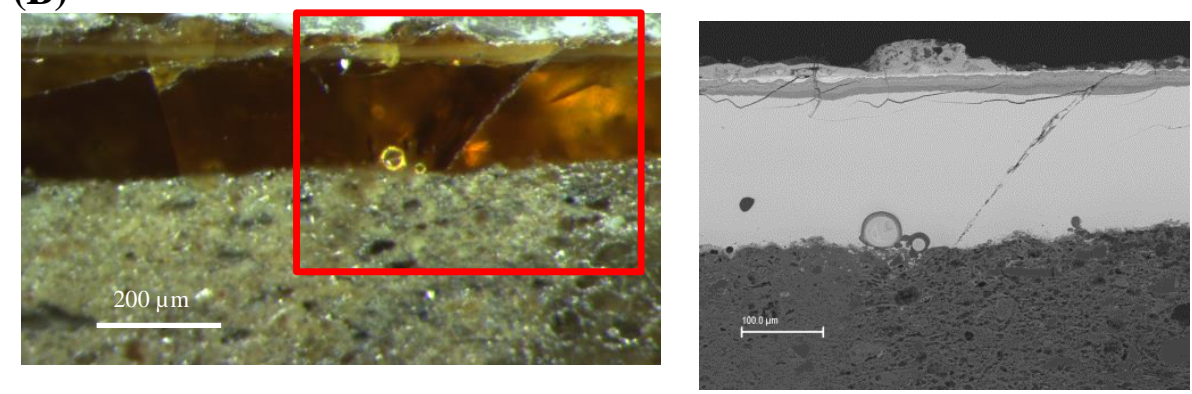

Figure 4. Monochrome and bichrome transparent glazes; Optical and SEM-BSE images of the glazes from (A) MX25 and (B) PH10.3.

The chemical composition of the glazes from the monochrome group, is fairly homogeneous, see Table 3: colours are green (PH8, MX20, MX23, MX25) obtained by the addition of copper with typical contents varying between 1 and $4 \% \mathrm{CuO}$ or honey (MX21, MX22 and PH20) containing higher amounts of iron, between 2 and $5.5 \% \mathrm{FeO}$. The mottled honey (MX22) has higher iron content in the dark mottled areas. PH20 has a honey glaze containing high iron (5.5 $\% \mathrm{FeO}$ ) and also copper (below $1 \% \mathrm{CuO}$ ) and the glaze appears filled with small crystallites of diopsides, not found in the other monochrome transparent samples. We have to highlight also that this sherd is the only one in the group that is moulded. Glaze thicknesses are very variable, between 70-300 $\mu \mathrm{m}$, except MX25 which is very thin $(20-50 \mu \mathrm{m})$ (see Figure 4A), although the glaze is flaking because of the presence of large cracks parallel to the surface and the postdepositional processes.

On the other hand, four of the bichrome transparent glazes have a honey outer surface, containing high amounts of iron (see Table 3) $(2-6 \% \mathrm{FeO})$, while the inner surface is green and contains copper $(1.7-2.5 \% \mathrm{CuO})$. Only one -MX26- is green outside and honey inside. Both copper and iron are basically dissolved in the glazes. Nevertheless, the addition of iron oxide to obtain the honey/brown colour also is demonstrated by the fact that some round particles of iron oxide are occasionally found in the honey/brown glazes. The glaze thickness is relatively homogeneous $(80-190 \mu \mathrm{m})$ and usually slightly thicker for the honey glazed surface. The 
exception is MX26 which shows a very thin glaze $(20-50 \mu \mathrm{m})$, although the glaze is again slipping down because of the presence of large cracks parallel to the surface.

The polychrome transparent glazes are characterised by the application of copper green and manganese brown decorations (Table 3), which protrude above a cream/greenish transparent glaze. Therefore we conclude that they were applied overglaze, see (Figure 5). This effect is enhanced by the presence of round partially dissolved quartz grains of various sizes in the green and brown areas of the glazes. In particular, the green glaze from PH18 shows large round undissolved quartz grains (Figure 5C). The use of manganese is a novelty with respect to the previous monochrome and bichrome glaze productions. PH18 has these colours embossed and splashed, inspired in Tang dynasty designs, similarly to a tradition documented in the Abbasid world (WATSON 2004). The undecorated glaze surfaces are transparent with a yellow-greenish tinge. All the glazes are high lead and rather pure, containing very low potassium, calcium, aluminium and iron, compared to the monochrome and bichrome glazes. Glaze thicknesses are variable, between 120-300 $\mu \mathrm{m}$ for most of the glazes and decorations, with the colour areas being thicker (see Figure 5A and Figure 5B). The green decoration from PH18 is extremely thick, $530 \mu \mathrm{m}$ due to the presence of large undissolved quartz grains (Figure 5C).

(A)

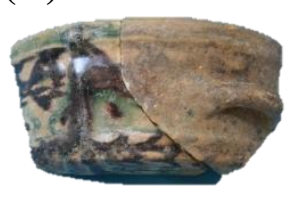

(B)

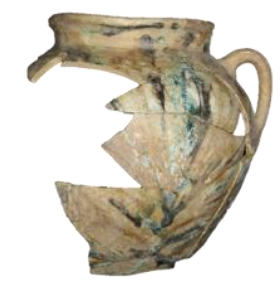

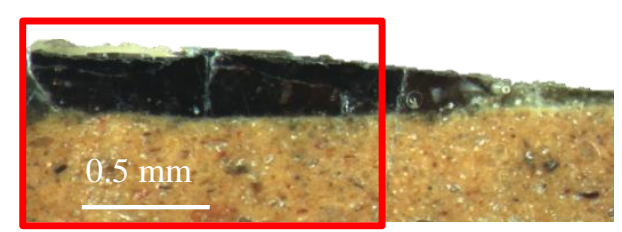
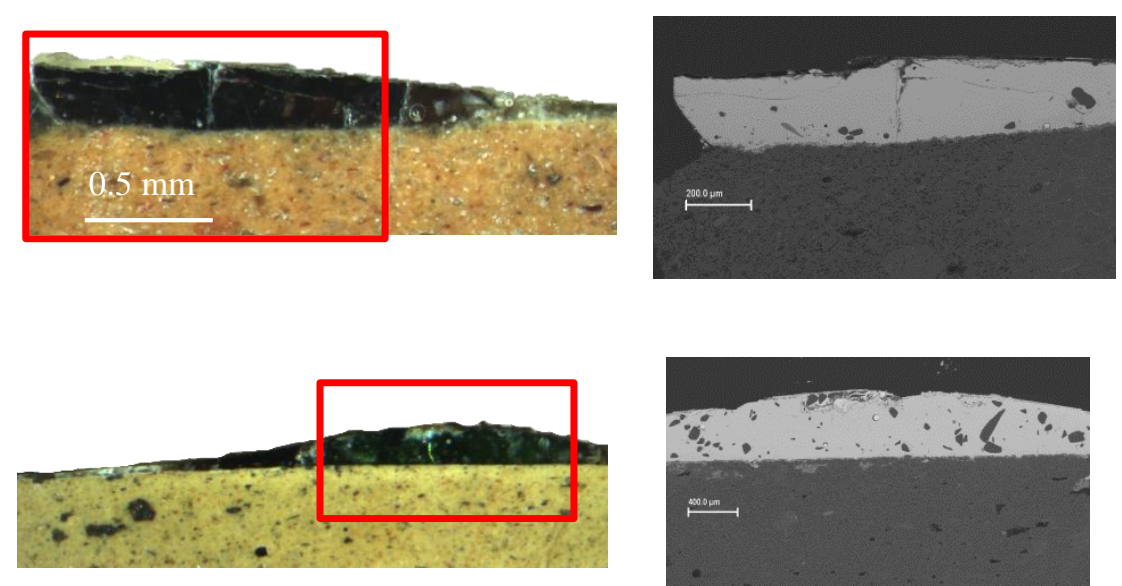

Figure 5. Polychrome transparent glazes. (A) brown and transparent glaze (PH15.2) and (B) green glaze (PH18).

\subsection{Tin-opacified glazes}

These glazes are of a lead-alkali type and contain $36-44 \% \mathrm{PbO}, 2-4 \% \mathrm{Na}_{2} \mathrm{O}, 0.6-2 \% \mathrm{MgO}, 1-$ $2 \% \mathrm{Al}_{2} \mathrm{O}_{3}$ and 2-4\% $\mathrm{CaO}$ (see Table 4). Tin is present in the form of very small cassiterite particles which appear well distributed in the glazes, both in the decorated and undecorated sides (Figure 6B) typical contents of about $10 \mathrm{wt} \% \mathrm{SnO}_{2}$. The tin content is slightly higher in the decorated surface than in the undecorated surface and also in the white areas than in the coloured areas. The colourants used are the same as in the transparent polychrome glazed wares; copper for green and manganese for brown/black. The coloured areas also protrude over the tin glaze surface, and, consequently were also applied overglaze (Figure 6C and Figure 6D). 
Table 4. Chemical compositions of Córdoba bulk tin-opacified glazes determined by SEM-EDS (wt\% normalised to $100 \mathrm{wt} \%$ ). The data are the average over at least two analyses taken in different areas of the glazes. Typical standard deviations are: 0.3 for $\mathrm{Na}_{2} \mathrm{O}, \mathrm{MgO}, \mathrm{K}_{2} \mathrm{O}, \mathrm{FeO}$ and $\mathrm{PbO}, 0.4$ for $\mathrm{CuO}$ and $\mathrm{Sn}_{2} \mathrm{O}, 0.9$ for $\mathrm{Al}_{2} \mathrm{O}_{3}$ and $\mathrm{SiO}_{2}$, and 1.5 for $\mathrm{CaO}$.

${ }^{1} \mathrm{~b}$ - brown glaze, g- green glaze, $\mathrm{w}$ - white, $\mathrm{w}^{*}$ - heavily altered white

${ }^{2}$ Dec- decoration, d-decorated, u-undecorated

\begin{tabular}{|c|c|c|c|c|c|c|c|c|c|c|c|c|c|c|}
\hline Sample & Glaze $^{1}$ & Side $^{2}$ & $\mathrm{Na}_{2} \mathrm{O}$ & $\mathrm{MgO}$ & $\mathrm{Al}_{2} \mathrm{O}_{3}$ & $\mathrm{SiO}_{2}$ & $\mathrm{~K}_{2} \mathrm{O}$ & $\mathrm{CaO}$ & $\mathrm{TiO}_{2}$ & $\mathrm{MnO}_{2}$ & $\mathrm{FeO}$ & $\mathrm{CuO}$ & $\mathrm{SnO}_{2}$ & $\mathrm{PbO}$ \\
\hline \multirow{4}{*}{ PH19 } & $\mathrm{w}$ & $\mathrm{d}$ & 2.9 & 1.1 & 1.3 & 35.9 & 1.0 & 2.7 & & & 0.8 & & 11.3 & 43.3 \\
\hline & $\mathrm{g}$ & $d$ & 2.6 & 0.9 & 1.2 & 35.8 & 1.1 & 3.1 & & 0.3 & 0.5 & 1.3 & 9.7 & 43.4 \\
\hline & $\mathrm{b}$ & $d$ & 2.4 & 1.1 & 1.5 & 36.9 & 1.3 & 3.3 & & 0.6 & 0.7 & & 9.7 & 42.6 \\
\hline & w & $\mathrm{u}$ & 2.1 & 1.1 & 1.1 & 37.1 & 1.3 & 3.2 & & & 0.6 & & 9.7 & 43.9 \\
\hline \multirow{4}{*}{ PH13.5 } & $\mathrm{w}$ & $\mathrm{d}$ & 2.6 & 1.6 & 1.8 & 35.5 & 1.6 & 4.0 & & & 0.9 & & 9.9 & 36.0 \\
\hline & b & $d$ & 2.8 & 0.9 & 0.9 & 39.9 & 1.7 & 3.1 & & 2.4 & 0.7 & & 8.3 & 39.3 \\
\hline & $\mathrm{g}$ & $d$ & 1.9 & 0.7 & 1.1 & 40.7 & 2.1 & 2.3 & 0.1 & & 0.8 & 1.2 & 9.4 & 39.9 \\
\hline & $\mathrm{w}^{*}$ & $\mathrm{u}$ & 2.3 & 2.7 & 4.7 & 39.3 & 2.5 & 5.8 & 0.3 & & 1.5 & & 3.2 & 35.8 \\
\hline \multirow{4}{*}{ PH14A } & $\mathrm{w}$ & $\mathrm{d}$ & 3.4 & 2.0 & 2.3 & 39.6 & 1.7 & 4.2 & 0.1 & 0.2 & 0.8 & 0.9 & 7.6 & 36.4 \\
\hline & $\mathrm{b}$ & $\mathrm{d}$ & 2.0 & 0.6 & 0.7 & 41.6 & 1.7 & 1.6 & & 4.0 & 0.6 & & 7.4 & 39.5 \\
\hline & $\mathrm{g}$ & $\mathrm{d}$ & 3.4 & 1.9 & 2.4 & 40.3 & 1.7 & 3.9 & & 0.2 & 0.9 & 1.4 & 5.2 & 38.1 \\
\hline & $\mathrm{w}$ & $\mathrm{u}$ & 2.2 & 0.9 & 1.5 & 45.3 & 3.2 & 2.6 & & & 1.3 & 0.2 & 6.6 & 36.0 \\
\hline \multirow{3}{*}{ PH50 } & w & $\mathrm{d}$ & 3.8 & 1.2 & 0.9 & 38.1 & 1.3 & 2.5 & & & 0.7 & 0.9 & 10.9 & 39.3 \\
\hline & $\mathrm{g}$ & $\mathrm{d}$ & 1.9 & 1.3 & 0.9 & 38.3 & 1.3 & 3.0 & & & 0.8 & 2.2 & 10.7 & 38.8 \\
\hline & $\mathrm{w}^{*}$ & $\mathrm{u}$ & 2.5 & 1.1 & 3.5 & 40.0 & 2.9 & 3.7 & & & 1.4 & & 1.6 & 42.8 \\
\hline
\end{tabular}

The glaze thickness is pretty homogeneous in this group, the undecorated surface being thinner $(125-200 \mu \mathrm{m})$ than decorated surface $(\sim 300 \mu \mathrm{m})$ (Figure 6).

Generally speaking the glazes appear quite heavily weathered, with lead-calcium phosphates and lead-calcium carbonates crystallising inside the bubbles, in the cracks and on the surface acting as cement for soil particles (Figure 6D). Due to weathering the glaze becomes more transparent, but as lead calcium carbonates are white and lead-calcium phosphates yellow, the surface looks dull with a powder-like appearance of a white or yellowish colour (Figure 6A).

(A)

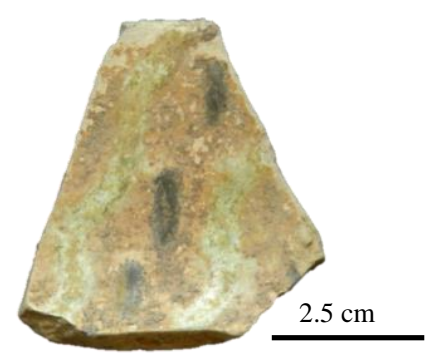

(C)

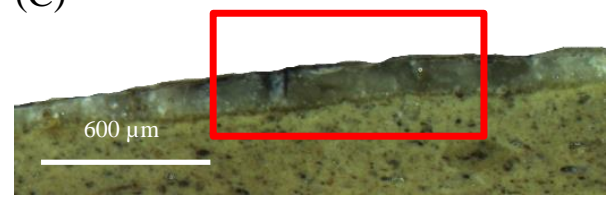

(B)

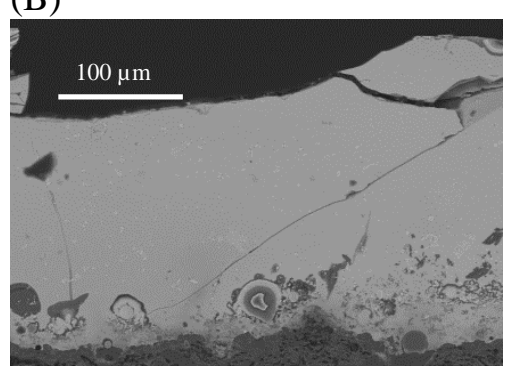

(D)

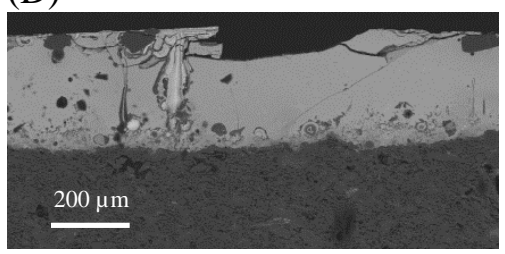


Figure 6. Tin glaze ware (PH13.5); (A) brown and green decoration (B) magnification of the glaze showing the cassiterite crystallites; (C) and (D) optical and BSE-SEM images respectively from a cross section of the brown decoration.

The presence of red areas in the inner areas of some green glaze decorations (Figure 7A) is related to the presence of small copper metallic nanoparticles (Figure 7B). This indicates that rather strong reducing conditions affected this area of the glaze.

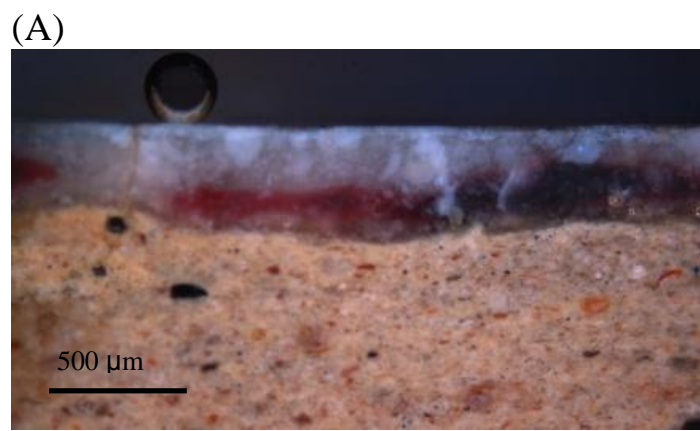

(B)

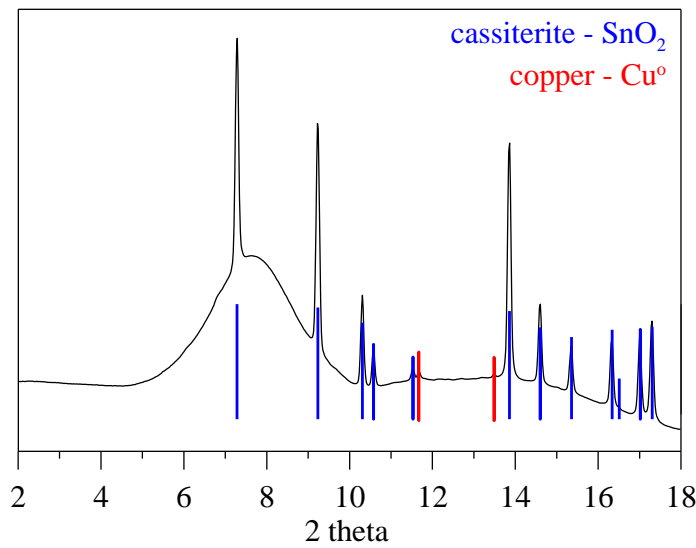

Figure 7. Tin glaze ware (PH50); (A) Optical image of the red layer in the green glaze (B) micro-XRD analysis of the red layer showing the presence of cassiterite and metallic copper nanoparticles.

\section{DISCUSSION}

In order to compare the base compositions of the glazes to which colourants have been added in variable amounts, it is convenient to remove the colourants and renormalise the resulting glaze compositions. In our case the colourants added are basically manganese, copper and iron; although part of the iron might already be present in the base glaze, iron oxide was certainly added in the honey and brown glazes. Then, the chemical compositions of the base glazes can be compared; Figure 8 shows the renormalized $\mathrm{CaO}+\mathrm{K}_{2} \mathrm{O}+\mathrm{Al}_{2} \mathrm{O}_{3}$ * versus $\mathrm{SiO}_{2}+\mathrm{MgO}+\mathrm{Na}_{2} \mathrm{O}$ * and also versus $\mathrm{PbO}^{*}$ for the different glazes. With regard to the transparent lead glazes productions, two groups are found: one including the monochrome and some of the bichrome glazes and a second one including the polychrome glazes and two of the bichrome glazes. The first group including monochrome and most of the bichrome glazes is characterised by the presence of higher potassium, aluminium and calcium and to a lesser extent higher sodium and magnesium. The presence of higher amounts of potassium, aluminium and calcium in the monochrome glazes might indicate either the use of a more impure glaze, or be the consequence of the dissolution of a larger amount of ceramic paste during the glaze firing. Nevertheless, considering that there is no relationship between the amount of calcium content in the ceramic paste and the amount of calcium dissolved in the glazes, this latter possibility seems unlikely. 
In fact, previous studies and archaeological evidence-have demonstrated that the lead glazes were fritted before their application onto the ceramic surface. Archaeological findings showed that a lead oxide and sand mixture was fired inside cooking pots which had the inside surface protected by a layer of a calcareous aluminium rich clay. As a consequence, the frits obtained were enriched in calcium and aluminium. Afterwards, the frits were crushed and mixed with water. Finally, the pots were dipped into this mixture and fired (MOLERA et al. 2009). The glazes are very homogeneous and do not contain crystalline precipitates. Consequently, the monochrome and some of the bichrome glazes containing higher aluminium and calcium are consistent with this procedure.

In contrast, the polychrome base glazes are very pure (containing low aluminium, potassium, calcium and also low sodium and magnesium) and richer in lead (high lead group) and consequently very transparent (Figure 8). This composition together with the presence of undissolved quartz grains (Figure 5) suggests that a mixture of lead oxide and sand was used to produce the glaze. This transparent glaze is thin and covers all the surface of the ceramic. The same mixture with the addition of manganese, iron or copper oxide was afterwards used to paint the colour decorations on top of the transparent glaze.

The tin glazes group differ from the transparent lead glaze groups (Figure 8) not only because of the addition of tin, but also because they contain higher amounts of sodium and magnesium. This suggests the addition of plant ashes to the glazing mixture. This is in very good agreement with the method of production described in the treatises, as well as with the data obtained from the white tin glazes produced in the Middle East (MATIN 2016), confirming that the tin glazes were obtained mixing a lead-tin calx, obtained roasting together lead and tin, with sand and plant ashes. 

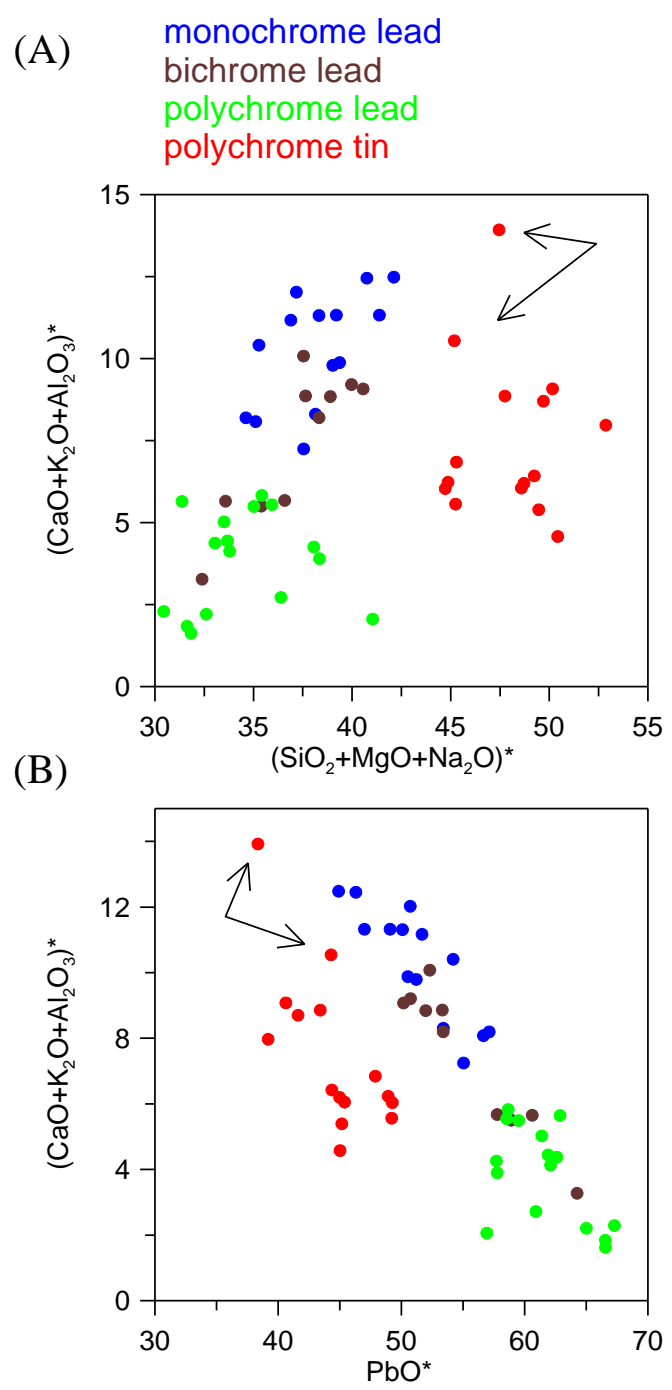

Figure 8. Glaze chemical composition plots; A) $\mathrm{CaO}+\mathrm{K}_{2} \mathrm{O}+\mathrm{Al}_{2} \mathrm{O}_{3}{ }^{*}$ versus $\mathrm{SiO}_{2}+\mathrm{MgO}+\mathrm{Na}_{2} \mathrm{O}^{*}$ and B) $\mathrm{CaO}+\mathrm{K}_{2} \mathrm{O}+\mathrm{Al}_{2} \mathrm{O}_{3}{ }^{*}$ versus $\mathrm{PbO}^{*}$ renormalized after subtracting the glaze colorants, for the different glaze types. The two glaze analyses marked with arrows correspond to the undecorated side of PH13.5 and PH50 which are very thin and appear heavily weathered.

Another particular feature is that the coloured glazes were applied on top of the white tin glaze, following the same technique as in the polychrome transparent glazes. On the other hand, the presence of metallic copper nanoparticles in the inner area of copper green glazes indicated the presence of local strong reducing conditions. This is consistent with the use of an organic glue (i.e. Arabic glue) to fix the colour glaze decorations over the tin glaze. This organic glueing material is completely burned during firing. In fact, red layers in copper green glazes are also found in some of the polychrome lead transparent glazes, suggesting that the same procedure might have been used.

In summary, three different glaze technologies coexist. While monochrome and bichrome glazes may be considered the continuation of earlier glaze productions, the polychrome transparent and polychrome white tin productions correspond to a completely new technology, as monochrome opaque glazes were not produced in al-Andalus, unlike eastern Islamic lands. Stylistically, the group has a large variety of forms (serving-dishes, bowls, pitchers, beakers, jars, oil-lamps), although they correspond chiefly to tableware. A common trend is the absence 
of foot in the serving dishes, the use of a large variety of decorative techniques (incised, applied, moulded, painted) and of decorative patterns (very simple, mainly geometric motifs).

In the Eastern Islamic lands, glazed wares appeared earlier. From the Levant -Palestine (TAXEL 2014), Jordan (WHITCOMB 1989) and Syria (McPHILLIPS 2012)- and Egypt (GAYRAUD, VALLAURY 2017) to the Middle and Near East (NORTHEDGE, KENNET 1994), monochrome, bichrome alkali or lead together with polychrome lead or tin glazes are widely documented from late $8^{\text {th }}$-early $9^{\text {th }}$ centuries. This shows that there was a wellestablished distribution network and trade roads, as well a market demanding this type of product.

Monochrome plain transparent glazes were already widely used in the Byzantine Empire since the beginning of the $7^{\text {th }}$ century (FRANÇOIS, 2005) and in early Islamic times with turquoise and green glazes (WATSON 2004). In al-Andalus, in the Emiral period, plain monochrome and bichrome green and amber glazes were produced in Pechina and monochrome brown glazes in Malaga (CASTILLO, MARTÍNEZ 1993; IÑIGUEZ, MAYORGA 1993). Furthermore, green and amber monochrome and bichrome lead glazes were found in Vega de Granada with similar composition to our transparent lead glazes (MOLERA et al. 2017).

High lead polychrome transparent glazes similar to our polychrome glazes were also produced by Byzantine craftsmen (ARMSTRONG et al. 1997). In early Islamic times, Raqqa workshops (before $\mathrm{AD}$ 809) show a large variety of tableware shapes, mainly with foot and underglaze decorations (FRANÇOIS \& SHADDOUD 2013; WATSON 1999; 2014). The same ware shapes were also glazed with lead, alkali and tin glazes. Similar shapes and glazes are repeated in contemporary contexts of Palestine (TAXEL 2014) and Egypt (GAYRAUD, VALLAURY 2017). Moreover, in the central Mediterranean, in Ifrīqiya (Tunisia), a fine and elaborated polychrome-transparent underglaze-painted tableware of Iranian influence (GRAGUEB 2017) was produced during the Aghlabid dynasty rule (Raqqāda after AD 876) (BEN AMARA et al. 2001) with continuity during the Fatimid period (10 $10^{\text {th }}$ century) (BEN AMARA et al. 2005). Other nearby sites such as Tahert-Tagdempt (Algiers) (DJELLID 2011) and Palermo (Sicily) (ARDIZZONE et al. 2017) which were directly influenced by the Aghlabid glazed tableware became local production centres. Early Tunisian tableware has hemispheric profiles with foot, yellow transparent lead glazes (CAPELLI et al 2013) and elaborated underglaze green and brown painted designs. All the above lead transparent polychrome glazed wares are significantly different from the Andalusi tableware from Cordoba, which has divergent shapes, absence of foot, high lead glazes and overglaze decorations. Polychrome transparent glazed ceramics other than those from Cordoba have not been documented in al-Andalus so far.

White tin-glazed wares reached their peak during the $9^{\text {th }}$ and through the $10^{\text {th }}$ centuries in the Middle and Near East, with the distinctive "Samarra" style of the Abbasid world (NORTHEDGE, KENNET 1994; PRIESTMAN 2011; WOOD et al. 2009): blue, green and plain glazes. Some green and brown decorations over white tin glazed wares are documented in Syria (WATSON 1999; 2014; SHADDOUD 2013). Analyses of these glazes show a similar composition to that of the al-Andalus tin-opacified glazes, indicating the use of a similar recipe, made using a lead tin calx to which plant ashes were added (MATIN 2016). On the other hand, in the central Mediterranean, the earliest evidence of tin glazed wares is documented in Tunisia and seems to coexist with a local lustreware production (Sabra al-Mansūriyya, mid $10^{\text {th }}$-mid $11^{\text {th }}$ AD) along with Fatimid Egyptian lusterware (WAKSMAN et al. 2014), hence AD post-972, which leads us to think that the al-Andalus tin-glaze technology began earlier (AD pre-929). Moreover, chemical analysis indicates that Tunisian glazes have lower lead content (20$30 \% \mathrm{PbO}$ ) than our tin glazes but similar to the Egyptian Fatimid lustreware. Contrarily to the 
polychrome lead transparent glazed wares, polychrome tin opaque Emiral wares have also been found in Vega de Granada (MOLERA et al 2017). The decorations were applied overglaze, like in the Cordoba examples; however, as is also the case in the later Caliphal polychrome tin glaze production, the tin glaze is applied only on the decorated side, while a honey or green transparent plain lead glaze is applied on the undecorated surface.

Finally, new decorative patterns and shapes (e.g. hemispheric dishes), different to those of the polychrome transparent lead glazed wares are introduced with the Andalusi tin-opacified glaze production. Nevertheless, both, polychrome transparent lead and tin-opacified glazed wares share the distinctive absence of foot and the overglaze application of the decorative patterns.

Consequently, with regards to the origin of both lead transparent and tin opaque technological traditions, the Tunisian connection seems to be completely discarded (ROSSELLÓ 1995), because of the different polychrome transparent glazing technique and the absence of earlier tin-opacified glazes. Moreover, and although some similarities between the Cordoba and the Abbasid productions can be traced (similar tin glaze recipe and decorative patterns, use of lead glazes, etc.), dissimilarities (overglaze decorations, absence of alkali transparent glazes, tableware shapes variances, absence of foot, etc.) are still more important, and do not support a clear link between them.

\section{CONCLUSIONS}

The assemblages studied here illustrate the beginning of polychrome and tin-opacified glazed wares in the far west of the Islamic world where artisans were introducing new shapes, glaze recipes and decorative patterns that did not follow the "official" standards that will become characteristic of the later Caliphal period. The late Emirate was a very short creative time, in the aftermath of a transitional political period that precedes the ensuing standardised green and brown tin-glazed production, controlled by the Umayyad power, during the Caliphal period (AD 929-1009), when the same shapes, glazes, colours and decorative patterns were repeated in the al-Andalus workshops, with only slight differences.

Neither the chemical composition of glazes nor that of the pastes have shed too much light about their provenance. The glazes are different for each production (monochrome, bichrome and polychrome lead transparent or tin-opacified glazes) while the body pastes are all fine calcareous. Nevertheless, the analyses point to a regional origin (meaning from al-Andalus, not necessary from Córdoba itself). In particular, monochrome and bichrome sherds containing white calcium-rich nodules are directly related to the glazed ware debris found at the Zumbacón workshop (Córdoba). In addition, evidence of contemporary tin glazed wares probably from workshops in the Vega de Granada has recently been identified (MOLERA et al. 2017).

Glaze technology did not start until the mid- $9^{\text {th }}$ century in al-Andalus, very late compared to other Islamic regions (late $7^{\text {th }}-8^{\text {th }}$ centuries) (TITE et al. 2015; WATSON 2014). As a result, the transitional stage from monochrome to polychrome transparent lead and to tin glazes is very short (20-30 years) compared with other territories where this process took over a century, as in central Mediterranean - Ifriqiya (Tunisia) and Sicily. In fact, the Córdoba assemblages studied show that once tin glaze technology was introduced, very late in the Emirate (beginning of the $10^{\text {th }}$ century) and after a brief coexistence period, polychrome transparent lead glazes disappeared completely.

Polychrome transparent glazes show a distinctive composition and methods of production from monochrome and bichrome glazes. Moreover, both, polychrome transparent lead and tinopacified glazed wares share the distinctive absence of foot and the overglaze application of the decorative patterns, although new decorative patterns and shapes were introduced with the 
tin-opacified glazes. These features do not seem to correspond with what was happening at that time across the Mediterranean basin and beyond, in the Abbasid world.

Our study shows that although glaze technology reached al-Andalus very late in comparison with the rest of the Islamic world, once the production started - initially as a small-scale luxury product addressed to a privileged market - the consumption spread very rapidly, soon catching up with the rest of the Islamic world. Nevertheless, the decorative techniques introduced are less varied than in other regions, with neither lustre nor cobalt blue decorations being produced.

Finally, as for the possible routes for the introduction of the lead and tin glazes in al-Andalus we can rule out Tunisia as a source, even if this has been traditionally considered as a likely connection. On the contrary, the Abbasid world appears a more probable connection, in particular with regards to the tin opaque glazes.

\section{Acknowledgements}

Elena Salinas is funded by the Marie Skłodowska-Curie Actions call H2020-MSCA-IF-2015 project IGATO. We are grateful to the funds received from Ministerio de Ciencia e Innovación (Spain) project MAT2016-N0748719-R and Generalitat de Catalunya project 2014 SGR 00581. The $\mu$ SR-XRD experiments were performed at BL04 MSPD beamline at ALBA Synchrotron Facility with the collaboration of ALBA staff. We would also thank Chris Doherty and Moujan Matin for their helpful contribution (RLAHA, University of Oxford).

\section{References}

Armstrong, P., Hatcher, H., Tite, M., 1997. Changes in Byzantine glazing technology from the ninth to thirteenth centuries, In La céramique médiévale en Méditerranée. Actes du 6e Congrès. Aix-en-Provence, 225-229.

Ben Amara, A., Schvoerer, M., Daoulatli, A., Rammah, M., 2001. “Jaune de Raqqada" et autres couleurs de céramiques glaçurées aghlabides de Tunisie (IX - X siècles), Revue d'Archéométrie, $25,179-186$.

Ben Amara, A., Schvoerer, M., Thierrin-Michael, G., Rammah, M., 2005. Distinction de céramiques glaçurées aghlabides ou fatimides (IXe- XIe siècles, Ifriqiya) par la mise en évidence de différences de texture au niveau de l'interface glaçure - terre cuite, ArchéoSciences, $29,35-42$.

Cánovas, A., 2006. Informe de la AAP en la calle María Auxiliadora 17 y calle Jesús del Calvario (Córdoba), (unpublished work).

Cánovas, A., Salinas, E., 2010. Actividad Arqueológica Preventiva en la calle María Auxiliadora 17 y calle Jesús del Calvario (Córdoba), Anuario Arqueológico de Andalucia 2005, 503-515.

Capelli, C., Waksman, Y., Cabella, R., Gragueb, S., Treglia, J-C., 2013. Il contributo delle analisi di laboratorio allo studio delle ceramiche nordafricane. L'esemplo di Șabra al-Manșūriya (dati preliminari). La céramique maghrébine du Haut Moyen âge (VIIIe-Xe siècle). État des researches, problèmes et perspectives. P. Cressier, E. Fentress (eds.). École Française de Rome, 221-232. 
Casal, Ma T., Castro, E., López, R., Salinas, E., 2005. Aproximación al estudio de la cerámica emiral del arrabal de Šaqunda (Qurțba, Córdoba), Arqueología y Territorio Medieval, 12.2, $189-235$.

Castillo, F., Martínez, R., Acién, M., 1987. Urbanismo e industria en Bayyana. Pechina (Almería), Actas del II C.A.M.E., II. Madrid, 539-548.

Castillo, F., Martínez, R., 1993. Producciones cerámicas en Bayyana. I Encuentro de Arqueología y Patrimonio. La cerámica altomedieval en el sur de al-Andalus. Salobreña, 1990. Granada, 67-116.

Castillo, F., Martínez, R., 2000. Un taller de vidrio en Baŷŷāna-Pechina (Almería). El vidrio en al-Andalus. Madrid, 83-101.

Djellid, A., 2011. La céramique islamique du haut Moyen Âge en Algérie (IXe-Xe siècles): les problèmes de son étude. La céramique maghrébine du Haut Moyen âge (VIIIe-Xe siècle). État des researches, problèmes et perspectives, edited by P. Cressier, E. Fentress (eds.). École Française de Rome, 147-158.

François, V., 2005. La vaisselle de table à Byzance: un artisanat et un marché peu perméables aux influences extérieures. M. Balard, E. Malamut, J.-M. Spieser. Byzance et le monde extérieur. Contacts, relations, échanges, 21, Publications de la Sorbonne, 211-223.

François, V., Shaddoud, I., 2013. Nouvel atelier de potier d'époque abbasside au sud de Tell Abou Ali à Raqqa, al-Râfidān, vol. XXXIV, 21-79.

Frochoso, R., 2001. Los feluses de al-Andalus. Madrid.

Fuertes, M.C., González, M., 1994. Nuevos materiales cerámicos emirales de Cercadilla (Córdoba): ensayo tipológico. Anales de Arqueología Cordobesa, 5, 277-301.

Gayraud, R.-P., Vallauri, L., 2017. Fustat II. Fouilles d'Isțabl 'Antar. Céramiques d'ensembles des IX et $X^{e}$ siècles. Institut français d'archéologie orientale. Fouilles de l'Ifao 75/Institut d'Archéologie Orientale, Le Caire.

Gragueb, S., 2017. La céramique aghlabide de Raqqada et les productions de l'Orient islamique: parenté et filiation. The Aghlabids and their Neighbors: Art and Material Culture in Ninth-century North Africa, Brill. Arts and Archaeology of the Islamic World serie. Leiden 341-361.

Gragueb, S., 2013. Le vert et brun de Șabra al-Mansūriyya. Kairouan et sa Région: Nouvelles Recherches d'Archéologie et de Patrimoine, In Actes du Colloque International du département d'Archéologie (1-4 Avril 2009), edited by N. Boukhchim, J. ben Nasr, A. El Bahi. Tunis, $317-$ 330 .

Ibn Hayyān, 2001. Crónica de los emires Alhakam I y SAbdarraḥmān II entre los años 796 y 847 [Almuqtabis II-1]. Trad. de Maḥmūd SAlī Makkī y Federico Corriente. Zaragoza.

Íñiguez, C., Mayorga, J.F., 1993. Un alfar emiral en Málaga. I Encuentro de Arqueología y Patrimonio. La cerámica altomedieval en el sur de al-Andalus. Salobreña, 1990. Granada, 117138.

Larrea, I., 2008. Memoria preliminar de la A.A.Pre en el E.D. SC3-Zumbacón (Córdoba) (unpublished work). 
Matin, M., 2016. Origins of Islamic Glazed Pottery Revisited: A Technological Examination of 8th-10th Century AD Ceramics from Islamic Lands. $\mathrm{PhD}$ thesis (unpublished work).

McPhillips, S., 2012. Continuity and innovation in Syrian artisanal traditions of the $9^{\text {th }}$ to $13^{\text {th }}$ centuries. Bulletin d'études orientales, tome LXI, 447-473.

Molera, J., Carvajal, J.C., Molina, G., Pradell, T., 2017. Glazes, colourants and decorations in early Islamic glazed ceramics from the Vega of Granada (9th to 12th centuries AD), Journal of Archaeological Science: Reports. 10.1016/j.jasrep.2017.05.017.

Moreno, M., Vargas, S., García, B., 2006. Informe Memoria de la Supervisión Arqueológica en la Antigua Posada de la Herradura. Córdoba, (unpublished work).

Northedge, A., Kennet, D., 1994. The Samarra Horizon, In: E. Grube (ed.) Cobalt and Lustre, The Nasser D. Khalili Collection of Islamic Art, V IX, Oxford: Khalili Research Centre, University of Oxford, 21-35.

Priestman, S.M.N., 2011. Opaque Glazed Wares: the definition, dating and distribution of a key Iraqi ceramic export in the Abbasid period, Iran, 49, 89-113.

Rosselló, G., 1978. Ensayo de sistematización de la cerámica árabe en Mallorca. Palma de Mallorca.

Rosselló, G., 1995. La céramique vert et brune en al-Andalus du $\mathrm{X}^{\mathrm{e}}$ au XIII ${ }^{\mathrm{e}}$ siècle. Le vert \& le brun. De Kairouan à Avignon, céramiques du $X^{e}$ au XV siècle. Marseille, 105-117.

Salinas, E., 2013. Cerámica vidriada de época emiral en Córdoba, Arqueología y Territorio Medieval, 20, 67-96.

Taxel, I., 2014. Luxury and common wares: socio-economic aspects of the distribution of glazed pottery in Early Islamic Palestine, Levant 46.1, 118-139.

Tite, M., Watson, O., Pradell, T., Matin, M., Molina, G., Domoney, K., Bouquillon, A., 2015, Revisiting the beginnings of tin-opacified Islamic glazes, Journal of Archaeological Sciences, 57, 80-91.

Waksman, S.Y., Capelli, C., Pradell, T., Molera, J., 2014. The ways of the lustre: Looking for the Tunisian connection, Craft and science: International perspectives on archaeological ceramics, 109-116.

Waksman, S.Y., Capelli, C., Cabella, R., 2017. Annexe: Études en laboratoire de céramiques islamiques du Caire: l'apport des fouilles recentes, In GAYRAUD, R.-P., VALLAURI, L., Fustat II. Fouilles d'Isțabl 'Antar. Céramiques d'ensembles des $I X^{e}$ et $X^{e}$ siècles. Institut français d'archéologie orientale. Fouilles de l'Ifao 75/Institut d'Archéologie Orientale, Le Caire, 383-414.

Watson, O., 1999. Report on the glazed ceramics, In P. Miglus (ed.), Ar-Raqqa I. Die Frühislamische Keramik von Tall Aswad. Mainz, 81-87, taf. 94-99.

Watson, O., 2004. Ceramics from Islamic Lands. London: Thames and Hudson.

Watson, O., 2014. Revisiting Samarra: the rise of the Islamic glazed pottery. Beiträge Zur Islamischen Kunst Und Archäologie, 4, 125-144. 
Wood, N., Doherty, C., Owen, M. R., 2009. A Technological Study of Iraqi Copies of Chinese Changsha and Chinese Sancai Wares found at Samarra, Gu Taoci Kexue Jishu 8: ISAC '09. Beijing, 154-180. 